Journal of Humanities, Social and Management Sciences (JHSMS)

eISSN: 2788-4791 (online)

https://doi.org/10.47264/idea.jhsms/2.1.17

Vol. 2, No. 1 (January-June 2021), 200-213

https://www.ideapublishers.org/index.php/jhsms

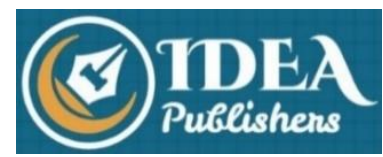

Research Article

\title{
Impact of Hydro-Politics and Kashmir issue between India and Pakistan
}

\author{
Sajjad Hussain $^{1}$ | Farrukh Faheem*2-3 | Saif Ul Islam ${ }^{4}$
}

1. Department of Political Science, Islamia University Bahawalpur, Pakistan.

2. Department of World History, Northwest University Xian, Shaanxi, China.

3. Government Postgraduate College, Rajanpur, HED, Punjab, Pakistan.

4. Department of Political Science, University of Buner, Sowari, Pakistan.

*Corresponding Author Emails: farrukhfaheem5050@gmail.com

Published: November 28, 2021

\begin{abstract}
This study primarily focuses on developing an exclusive model, generally explaining the importance of international rivers in the relationships of the nations and particularly interlinked conflict over Kashmir and the Indus River. Conflict is a fact among nations caused because of disputed lands or un-decided borders linked to valuable resources or due to political and ideological differences. Historical differences between Pakistan and India especially about water distributions can leads them towards war. So far, they had fought three wars due to Kashmir's un-resolved issue and an upcoming one could be forecasted to control water resources originating from occupied Kashmir. According to the neo-realistic point of view, this study examines the conflicting interests among India and Pakistan, which are related to Kashmir, and claims that it is not just religious but also geographical as it is connected to the control of river waters. There is very limited significant research present that primarily focuses on this facet of India and Pakistan's relations. The current literature expresses their conflict as of ideological, cultural, and political nature. This model-based research addresses the relationship of water and other related sources to war and peace through a rational research method demonstrated by broadly observed data.
\end{abstract}

Keywords: South Asia, India, Pakistan, Kashmir, river's water, hydro-politics, interstate river resources, conflict resolution.

\section{How to Cite:}

Hussain, S., Faheem, F., \& Islam. S. U. (2021). Impact of Hydro-Politics and Kashmir issue between India and Pakistan. Journal of Humanities, Social and Management Sciences (JHSMS), 2(1), 200-213. https://doi.org/10.47264/idea.jhsms/2.1.17

Publisher's Note: IDEA PUBLISHERS (IDEA Journals Group) stands neutral regarding jurisdictional claims in the published maps and institutional affiliations.

Copyright: ( 2021 The Author(s), published by IDEA PUBLISHERS (IDEA Journals Group).

Licensing: This is an Open Access article published under the Creative Commons AttributionNonCommercial 4.0 International License (http://creativecommons.org/licenses/by-nc/4.0/) 


\section{Introduction}

Water, like religion and ideology, has the power to move millions of people. Since the very birth of human civilization, people have moved to settle close to it. People move when there is too little of it. People move when there is too much of it. People journey down it. People write, sing, and dance about it. People fight over it. All people, everywhere and every day, need it (Gorbachev, 2000).

Climate change across the globe is sparking conflict as people are struggling over falling resources of water. In this regard the fight over water could quickly escalate between India. The matter is worse because both have nuclear arms. Pakistan and India have had a long history of rivalry since their birth from the British empire. They have signed an agreement over sharing water from the Indus River and its tributaries. The Waters in Indus, flow from Indian occupied Kashmir that further aggravate the situation. An agreement was carved up between India and Pakistan under the 1960 Indus Water Treaty with the financial and technical help of the World Bank. "The Indus Waters Treaty was signed on 19 September 1960 by India, Pakistan, and the World Bank" (World Bank, 1960). Although Indus Water Treaty is an exemplary agreement between states to resolve their waters disputes, but it seems that interstate relations between India and Pakistan are heading towards an impasse because of water scarcity in these countries. "The treaty is often cited as a success story of international riparian engagement, as it has withstood major wars between the two signatories (in 1965 and 1971), several skirmishes over water distribution, and derivative territorial concept" (Rausching, 1983).

Intrastate circumstances are as significant as interstate circumstances in impeding South Asia's progress toward a more cooperative model of river resource management. Many reasons are a hurdle to bring peace and security to South Asia. The scale of national river resource problems, requirements, and development plans; second, the inefficiencies associated with irrigation use of water resources; and third, structural and systemic problems connected with the national management of water resources. Water distribution within the country is also a major hurdle in making Pakistan and India nation- states. In India, its states Punjab, Haryana, and Rajaisthan have disputes over river's water distribution. In Pakistan, "the provinces of Punjab and Sindh continued to compete for water, and each needed to ensure that any agreement with India accounted for its needs" (Michel, 1967). Such matters can be aggravated in the future to fulfil states/provinces' needs of water into a war.

In Pakistan, for example, the political situation was a fragile balance between different interest groups which put 'conflicting demands and pressures on the central government' all of which produced 'a political climate of confusion and conflict' (Tayyeb, 1966). This work argues that the region's failures in resource management could bring a catastrophe for region poor nations generally and between Pakistan and India particularly if a viable solution for Indus water system distribution will not be implemented. So, this research focuses on the investigation of those unidentified unique conflicting factors in the Indus Basin which are related to political beliefs, tactical formation, and rivalry among India and Pakistan and similarly realizing the situations that force the arch-rivals to an agreement on essential issues and delaying governmental agendas.

It primarily focuses on explaining the causes behind the settlement of Indus water conflict between both nations such that, although being the prime reason behind the Kashmir conflict, 
it has been dominated by other issues in the relational analysis of both nations. Similarly, "in winter 2001-2002, against a backdrop of deteriorating Indo-Pakistan relations, notably the attack on the Indian parliament in December 2001, statements were made in India that it would unilaterally abrogate the Indus Waters Treaty" (Dawn, 2002).

\subsection{Historical importance}

Historically India and Pakistan conflict originates because of those harsh and deadly situations because of which both the nations emerged on the globe in 1947. The conflict between Kashmir and Indus is caused by the Radcliffe boundary award. The unjust division of British Punjab at the Subcontinent's partition gave India the benefit of water control of West Punjab (Pakistan) as it controls the headworks of two rivers and solely links India and Kashmir through the land. Eventually, by captivating fragments of Kashmir, India got accessibility to the watershed regions of the entire Indus River and also contributes to the origin of other rivers.

Maharaja Hari Singh, Kashmir's monarch presented a 'Standstill Agreement' to both countries to secure his independence and continue his rule. It was accepted by Pakistan but denied by India. The Kashmiri Muslims began to rebel against this arrangement, thus affirming their adherence to Pakistan. India entered its army on $26^{\text {th }}$ October 1947 in Kashmir, professing that Maharaja had signed an agreement with it. "With irrigation important to an agrarian economy in the basin, irrigation was extended under the British in the provinces of Punjab and Sindh" (Wescoat Jr et al., 2000).

The real political nature of the Kashmir dispute arose when India blocked Pakistan's river water on $1^{\text {st }}$ April 1948; it hugely threatens Pakistan's survival and immediately gathered immense response from the international community. Indian government declares its sole right on the waters of international rivers emerging from its land. After more than a decade-long dialogue and mediation, beyond public evaluation, under the strong influence of the World Bank, it is settled as the Indus Waters Treaty (IWT) in 1960. It's acclaimed internationally as a method of conflict resolution; however, some political critics questioning the sincerity and hostilities of their respective leaders were burnt to ashes. Instead, the countries negotiated an international water treaty and have main- tainted it for over 40 years through two wars and the nuclear era. In trying to explain India and Pakistan's successful cooperation over water, as recommended by Biswas (1992).

The Indian Government is continuously violating the IWT and developing projects on Pakistan's rivers to manage the water flow and now with the help of the Afghan Government, it is trying to worsen the water crisis in Pakistan by constructing 12 different hydro projects generating 2406.3 MW of electricity and storing 2,650,308 acres feet of water on the Kabul River which originates in Afghanistan and Jalalabad, joined by the Kunar River having its origin in Pakistan. It makes Afghanistan and Pakistan upstream and downstream basin countries with regards to the Kabul River.

If the Afghanistan government completes these projects, they will store around 4 million acrefeet of water and ultimately reducing water flow towards Pakistan that severely affects around 3 million people along with the agricultural land in Pakistan and could jeopardize Afghanistan and Pakistan's relations. As Alvi (1962) and Alam (1998) concluded that "all the ingredients were present - two enemies engaged in a wider conflict; a riparian completely dependent upon 
the Indus waters; water scarcity despite large average runoffs; and poverty preventing the construction of infrastructure- to offset this scarcity" that in future can caused a war between Pakistan and India.

\subsection{Statement problem}

This research formulates different dimensions claiming that neo-realistic concerns among the hostile neighbouring nations can cause dispute and settlement; it highlights the contest for controlling significant water resources as a problem of high politics among their relations. It elaborates when hostile nations settle on important concerns and why they put political issues out from active development. It inquires the connection between the Indus waters and the Kashmir contest and explains its political role, systematic planning, and hostilities between India and Pakistan. This study strengthens the faith of geographical legislators that essential resources like oil, gas, coal, minerals, water, and sea lanes can cause dispute among the nations, and increase the importance of controlling the territorial freshwater resources.

\subsection{Hypothesis}

If arch-rivals are not able to reach an agreement, then, they go for accommodation on national importance matters and delayed the political way.

\subsection{Research questions}

The reason behind this investigation is to identify that why a clash is present between India and Pakistan on water and how to solve it. Precisely it answers the following questions.

- What are the chief conflicts and concerns of Pakistan and India over water issues?

- How can this issue pertain to the survival of Pakistan as an agrarian country?

- Have water resources are protected geographically by demarcation?

- Do territories explicitly captivated by the rivals restrict access to water resources?

- Does the upper riparian ever use water as a weapon?

- Is the territory of Kashmir hydro strategically important?

- What can be the possible role of river water resources in relationship of both countries?

\subsection{Significance and objectives of the study}

It primarily focuses on discovering the importance of the control of water resources related to different aspects of the Kashmir discord regarding neo-realistic theory. It also focuses on the problems regarding the mediation process and also explains the role of mediators and the problems caused by their wrong attitudes. It also elaborates how nations unwillingly follow accommodation as a recommended policy for protecting their primary national and international interests. The literature regarding the security aspects of the Kashmir issue under the neo-realistic approach is rare; it contributes to creating a theoretical model elaborating the diplomatic nature of conflict and accommodation among nations. This research also bridges the gap between theoretical and practical aspects and also provides new areas for research.

This research study discloses the geographical and socio-economic dimensions that are innate 
in the hydro-strategic nature and significance of Kashmir which is many times mistakenly represented as a political and ideological concern. Hence, uniquely it explains the distinct as well as relational aspects of geographical, social, economic, environmental, and security issues related the Kashmir. Normally, the environmental and biological aspects are not considered as a threat to the fiscal or security situation of the rival nations, so are not considered as a reason behind the war. Though, this research proves that the economic and military balance between both nations is strongly influenced by the evolving environmental chaos in Pakistan. It tries to provide solutions to critical questions and guidelines to policymakers regarding the Kashmir dispute and water resources attached to it.

\section{Literature review}

The current literature gives abundant information on the importance of international rivers regarding disputes and their solutions between nations, although it did not provide information about such agreements those lead towards improving their relations and ultimately achieving peace among nations. The information regarding the critical evaluation of such agreements between the everlasting enmities and their effect on the extensive relationship is not present in the literature. It emphasizes two opposite schools of thought: "water causes war" and "water causes peace".

Wirsing (2007) argued that cooperation regarding river resources between and among most of South Asia's co-riparian states (India, Pakistan, Afghanistan, Nepal, Bhutan, and Bangladesh) was severely limited. Many things impeded it, we observed, including deeply entrenched interstate animosities rooted in the region's history, incommensurable national interests and policy priorities, and a paucity of either bilateral or multilateral agreements and institutional frameworks to facilitate dialogue and foster compromise. But she missed providing an acceptable conflict management model to solve water disputes between Pakistan and India.

Similarly, Ali (2008) in his article discussed the Indus water treaty that was signed between India and Pakistan in 1960. The distribution of environmental resources (Indus and it is tributary rivers) as a potential contributor to conflict has been the subject of considerable research, and these linkages have dominated the post-Cold War interest in environmental security. But these studies only covered the legal and technical aspects of the Indus water treaty. It failed to comprehend the future conflict on Indus rivers system water distribution between India and Pakistan. Another important work on this issue was done by Salman and Kishor (2003) in which they discussed in detail, conflict and cooperation mechanisms on the South Asian rivers system. This project was funded by the World Bank, which was also the guarantor of the Indus water treaty.

Alam (2002) explains explaining this Indo-Pakistan cooperation, which is specifically over water, the critical feature that emerges is that through cooperation the countries were able to safeguard their long-term water supply. She also believed that 'The water wars rationale predicts that countries will wage war to safeguard their access to water resources, especially if there is water scarcity, competitive use, and the countries are enemies due to a wider conflict'. But this study is inappropriate to provide any workable model to resolve the future conflict between India and Pakistan. The works of Tabassum (2001), also enlighten the new reasoners to provide a basic insight about the Indus water system but it lacks in providing a conflict resolution model. 
Water disputes are closely related to political, strategic, cultural, and faith-related issues. Therefore, historically the wars were never fought over water. Besides, many times it is not related to political developments. Water scarcity and environmental issues coupled with population growth and unequal resource distribution are aggravating and causing disputes domestically as well as internationally, but the problem is, it is yet to be proven that water is the lone source of conflict and war among nations. The only pertinent question of upcoming water inadequacy and dispute is due to a possible increase in the contest over the Jammu and Kashmir land, being a significant source of fresh water. Some studies claim to have a relationship with each other.

International law provides beneficial rights to the countries if they don't affect lower riparian in a harmful and hazardous manner. It is generally followed by the nations, but it is not related to the settlement between India and Pakistan regarding Indus water. So, if any country violates the agreement the matter refers to the International Court of Justice for settlement as they questioned their rights on riparian rights before signing the treaty. The literature provides much information regarding the role of the terrestrial qualities of land possessing those valuable resources in causing conflict. If borders are not properly defined, they also lead towards warlike in the case of Ireland, Palestine, and the British Punjab.

This passage defines and formulates a thesis of about two primary notions: "water a source of war" and "accommodation as recommended security strategy" among arch-rivals. It focuses on sorting out all aspects causing dispute and contributing to water war among nations and vice versa. The purpose is to design a model with detailed discernment of correlation between water, war, and peacekeeping in view in the relationships of concerned opposing nations in general and India-Pakistan dispute regarding Kashmir in actuality. As Hurts says, "although there is considerable rivalry among nations over the possession of such things as oil, gas and uranium, the most dangerous rivalry between countries can be for the possession of water, one of the elements without which man cannot exist" (Hurst, 1956).

There is no doubt about the fact that water is essential for life, economy, and environmental harmony in the world. Rarely, it may be possible that any other natural resource effects such widespread areas of human life from micro to macro levels, its life or death because "every living being is made from water". Usually, it has been present in a plentiful amount, nearly a free product. The situation is becoming different swiftly as its scarcity becomes an international problem for existence and harmony. Researchers are claiming that soon it will cause wars among nations and global peace will be in hot waters. United Nations Security Council (UNSC) report has given prime concern to Indus water dispute among other great perils of water disputes (Presse, 2001)

Nevertheless, historical preview on international relations presents several instances where even the bitter enemies agreed-upon water distribution avoiding war, but never proved a successful facilitator for peace. Generally, the controversies were persistent, and they did not give up on their territorial rights. India and Pakistan 's relations are so far the best instances. Their controversy embeds all the aspects of disruptive international relations which expand from a supposed politics to real politics. Nevertheless, in the 1960 Indus Waters Treaty; an agreement has been made by the two states on the diversion of rivers; it has not resolved any disputes, so there is no peace. Most importantly, none of the two states gave up on their historical right to the state of Kashmir. Both India and Pakistan agreed on each other's 
demands, but they never bargained on the state of Kashmir, which formulates the prime route of the research.

Both states have had grave concerns over the Treaty (Energy and Water, 2002). The Indian government deliberately tried to abolish the Treaty to hurt Pakistan and it was extensively published in the newspapers of May 2002. In Pakistan, the era of General Ayub Khan is openly criticized for surrendering to the pressure of the Indian government, World Bank, and the US government, to give away the water of its rivers to India. According to international organizations through this treaty, India received $12 \%$ more water than its actual right. In Pakistan, different politicians express their grave concerns towards this treaty and some of them suggest the government buy water from India, some criticized that probably it's the only pact on the earth in which a 'natural resource' was 'sold out. Some Indian critics have a point of view that Pakistan's prime objective regarding Kashmir is to protect its water resources. To have a political solution India and Pakistan must sort out the issue of water, otherwise, war is inevitable.

The situation of fresh water in Pakistan is becoming very crucial. The river water flow is deteriorating virtually and the water availability to every Pakistani has reduced to less than 1000 cubic meters instead of 5600 cubic meters at the time of independence. About 50 percent chances of loss by the year 2010 making it hard for wheat and cotton sowing (Outlook, 2005). Likewise, "This is reinforced by the large seasonal and annual variability in water availability, which is masked by large average annual runoff, 150-200 km3. For example, the Indus River measured at Kalabagh can change from $70 \mathrm{~km}^{3}$ during the summer to $12 \mathrm{~km}^{3}$ during the winter" (Gulhati, 1973).

Keeping in view the previous war history between the two atomic powers on Kashmir and other issues, there is much likelihood that there will be a third one if they don't sort out their difference. Why is it so and why they are so reluctant in solving it these are the three reasons? Three major perspectives may prove an answer for the Kashmir issue. It is a general perception that this issue is a religious one as Kashmir is a Muslim majority state which is an unfinished partition business. So, if a Muslim ideology-based Pakistan and so-called Hindu extremist secular India try to come on certain terms then the political pressure will be huge from both sides as symbolically it is a matter of national pride and integrity for both countries.

Secondly, it is a political controversy. The people of Kashmir want freedom and they were promised to be given this right by the United Nations Security Council in 1948 after the issue is settled between India and Pakistan but it is still unsolved between these two. The disheartened Kashmiris then became aggressive and began to get their rights with violence, which is increasing day by day. Pakistan morally supports them in their right to selfdetermination. So, it's an issue on political as well as on human rights grounds but India criticizes Pakistan for their support to Kashmiris.

On the last aspect, it is the main idea about Kashmir that it is a political dispute. It is the origin of one of the world's largest water systems affecting the largest populations in the world. "If India were [sic] to give up control of Kashmir - whether to Pakistan or an independent regime of some sort-it would lose its status as an upstream riparian and, therefore, much of its clout in determining the river's future us" (Klare, 2002). This affirms that the compression of the water flow is a matter of 'life and death, for India, and Pakistan. 
This study suggested that the Kashmir issue is primarily a political controversy. It is neither ideological nor intimate controversy. The importance of this territory is increasing day by day for India and Pakistan as the water resources are depleting and after capturing some areas of Kashmir in 1963 by China, the dispute is becoming global. Pakistan and China are developing China Pakistan Economic Corridor (CPEC) in those areas which India claim is its part and part of Kashmir. "An energy planning working group of the CPEC has also been established and has initiated a fast-track implementation of power projects associated with the CPEC (Rehman et al., 2018). According to CPEC projects, China will help Pakistan to overcome its energy shortages by building of Basha and Dasu Dams on the Indus River. Such hydro power projects can bring the regional powers Pakistan, India, and China into a direct conflict. So, the solution to this issue is of prime importance otherwise it could lead the world to a third world war.

\section{Theoretical framework}

Generally, the disposition of a state in terms of identity and non-identity issues in the international system is treated equally. To develop an elaborated model, it is necessary to work out the theoretical perspective of these issues. For example, classical realism sees power politics and geopolitics as one, thus focuses on international structure as discorded one and resulting in disputes. Contrarily liberals' states, global states rely on each other thus increases, cooperation. Constructivists further verified it by carefully stating that nations prosper by cooperation (Barnett \& Duvall, 2005). The strategies of neo-realism focus on protecting national benefits and on increasing security and maximizing power (Keohane, 1986). Thus, developing international relations on a rational basis by keeping in mind cost and benefit analysis. Despite having negotiations on the interstate relations, the theories that have already been mentioned do not consider water as an explicit issue among the two nations. This is possibly because of the inadequate significance of the matter globally, as they consider it, a premature thought.

Although there is a scarcity of an explanatory model on the subject, neo-realist and neoconstructivist are still unable to clarify the matter. Water dispute is normally associated with the rational approach of the countries under the neo-realistic school of thought but the neoconstructivism emphasis on the stability and continuity of the system. Territories are empirically related to the development of conflict among the nations and if they are abundant in natural resources then conflict aggravates many folds. So, neo-realists explain such a situation as a 'mutually hurting stalemate' centred around profit and loss, but according to neoconstructivists cooperation is a better approach. Both sides provide an empirical theoretical approach helping in developing an elaborated model for explaining the importance of Kashmir strategically, economically, and particularly on the Indus Waters front between arch-rivals India and Pakistan.

\section{Variables}

This research uses three types of variables. One comprising of those independent ones which lead towards war because of water resources or provoke ecological contests including the terrestrial dynamics, like location, boundaries type, landscapes (like regulated frameworks that are both natural and man-made); economic restrictions, like lower riparian reliance on resources, ecological changes, usage and development of land and water resources, and national influences, such as internal limitations and pressure from outsiders. 
Other independent variables generate a settlement among prevailing controversies on water resources. It includes the existence of any of the detrimental conditions (like military, economic or socio-political), the necessity of minimizing losses (in international relations), and the degree of domestic reforms obligations (within the country), and the presence of an arbitrator serving as an external international influencer.

The third set of interdependent variables influences the settlement process including fruitful conversational negotiations, the culture of negotiation to resolve disputes, endorsing a powerful third party, a delay of political issues, backdoor diplomacy, and forming a legal contract. They are briefly explained in the following model which intertwines the concepts of water-war and water as a cause of making peace and also clarifying the importance of the Indus River waters in the relationship of India and Pakistan.

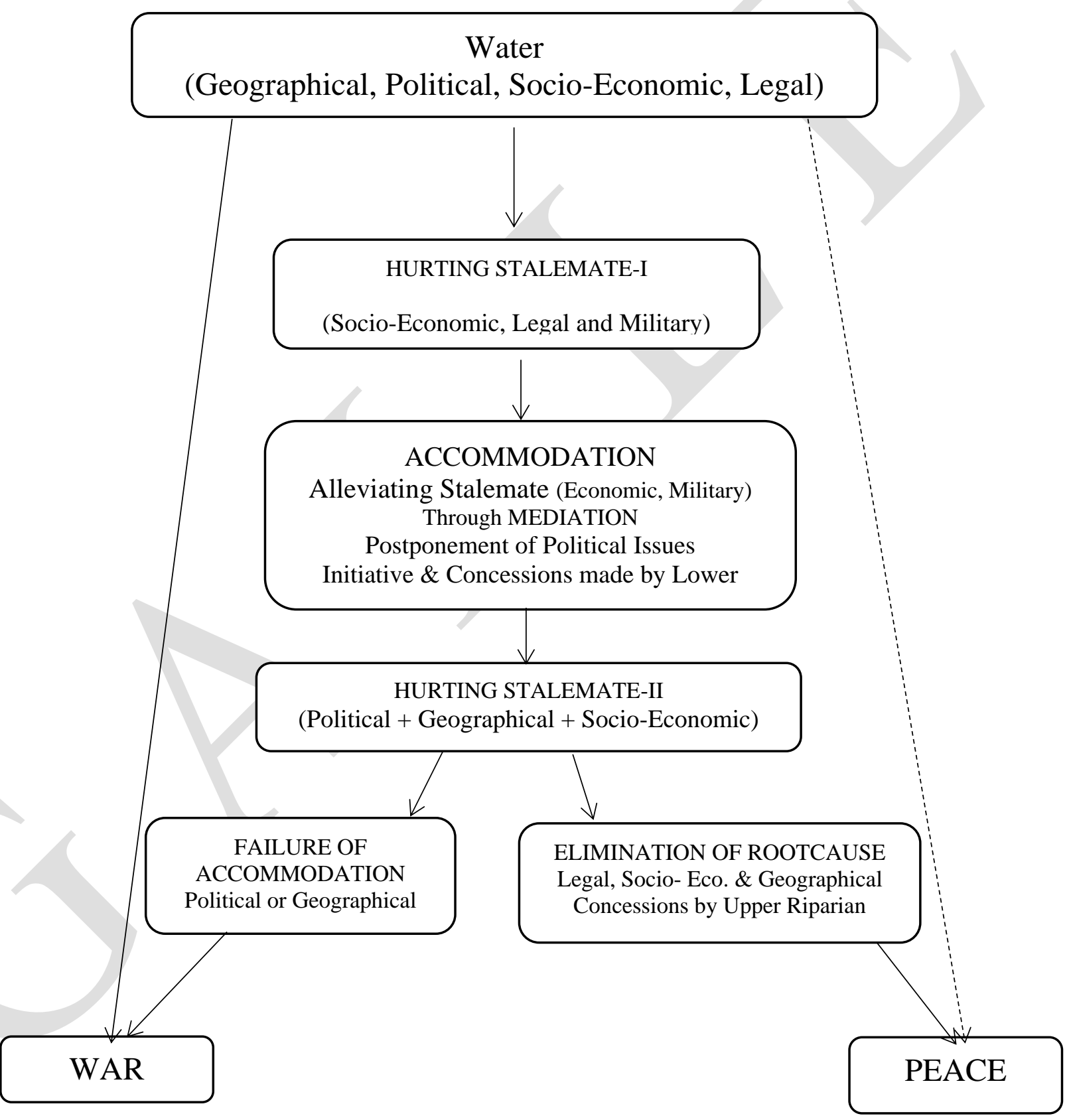




\section{Research methodology}

The qualitative interpretive methodology is used in this research to elaborate and combine the comparison made that is to signify affiliations between explanatory factors and in an inspection of the normal patterns that are rarely found in quantitative analysis. This research method is applicable in a variety of case studies. In some social contexts, however, mono-causal explanations are persuasive; however, a mere detailed result may be produced by an exclusive feature regardless of others. The method of settlement is inappropriate to account for various and theoretical antecedents. Contrary, the difference goes further, "a double application of the method of agreement (Charles, 1987).

It explains that if results are different from a dependent variable having similar values for the independent variable, then the independent variable is not a significant reason for the result. Such conditions do not exist every time: in the case of water disputes, various normal factors surface, separately, to be neither satiate nor fundamental to generate the consequences of disputes. This expounds on the problem of various complications on many occasions. Conflicts rarely or never originate as a consequence of an exclusive and cosily identifiable normal factor. However, certain factors contribute to the occurrence of disputes. As has been shown in this passage, particularly, the variation among unidentifiable and boosting factors, and among those which pertain either to propensity or provocation, are significant in identifying the various factors which enhance disputes.

\section{Limitations of the study}

This reach is limited concerning the non-identity aspect of conflict and a distinctive territory as a consequence of the unjust division of British Punjab between India and Pakistan by Radcliffe, links the state of Kashmir or the catchment areas of the whole of the Indus basin was beneficial to mitigate the chances of conflicts among them. Assessing the descriptive value of a factor between others is, by necessity, systematically complex stuff. Specifically of a multifaceted public matter such as war and accommodation among arch-rival riparian, the investigator has to face the problematic intricacies of reality. Some researchers have tried to explain the simplification of intricacies of reality by professing that "any social system is as complex as the theory developed to study it thereby denying any intrinsic complexity to social phenomena outside the control of the researcher".

\section{Analysis and recommendations}

This study analyses the state's discourse concerning the management of river water and identifying that is there any territorial, political, or legal changes are made. Water issues are normally associated with security and mostly negotiations took place between India and Pakistan, neglecting the contributions of Afghanistan and China, except at the time of discussing dam projects. The changing political and water-related dynamics demand the involvement of China and Afghanistan to resolve the water crisis in a better way. This study tries to explain their involvement and contributions in resolving this conflict. It also explains the importance of dams and their linkage to national development, their control over water in the subcontinent and neighbouring countries.

National water policy of India, Integrated Water Resources Management (IWRM) emphasizes 
the need to promote the "integrated and sustainable development and management" of water. It focuses on the Central Water Commission's Dam Rehabilitation and Improvement Program, which explains that a large number of water projects are under development, thus increasing the water storage and power generation capacity and in reality, blocking the water flow to Pakistan.

Pakistan's Water and Power Development Authority (WAPDA) has published a report on "Integrated Water Resources Management in Pakistan" which focuses on the need of building new water projects to improve water supply, storage, and power generation, the purpose of IWRM is to utilize and defend this construction.

The base of dialogue between India and Pakistan over water conflict differs and focuses on the development and sovereignty narratives. Pakistan claims that dams are for national survival as they generate energy and store water; whereas Indian statements promote the "accelerated development" of water projects for "optimal usage of water allocated to India" under the Indus Water Treaty (IWT). Development and sovereignty make it a political issue and the state's responsibility, avoiding negotiations.

Pakistan's Indus Water Commission's capability to guarantee Pakistan's rights under the Indus Water Treaty has led to questioning many times. Jamaat Ali Shah who was the former Indus Commissioner was accused and said to be an ally of the Indian league with India as he claimed that India was not stealing Pakistan's water and has the right to establish dams on Pakistan's rivers. After Shah, political, national, and security narrative regarding water against India was dominated in Pakistan.

Afghanistan's Salma Dam focuses on "improve the lives of thousands of people" and according to the Afghan President being "committed to control and manage Afghan waters and use them for the development of Afghanistan which will bring economic prosperity and harmony as sustainable development". Afghanistan claims that its dams are related to constant growth and to enhance the standard of living of its people by controlling and managing water as an appropriate way of achieving goals.

Pakistan claims that its water projects are mandatory for solving its water problems and for socio-economic development. Pakistan is running low on the water supply and facing a severe crisis of power shortage. The solution to these problems is "to construct storage facilities and improve flood regulation" and "immediate construction of storage dams, not for power alone but for water storage is essential".

India and Pakistan's negotiations regarding water are based on IWT focusing on developing hydro projects. Pakistani Government repeatedly stated that India is not potentially and sincerely confining to its obligations regarding Indus Water Treaty. The plans of underconstruction projects are violating the specified criteria according to the Indus Water Treaty.

India continuously made attempts to disrupt Pakistan of its major concerns under the IWT and has expounded to the fact whether a dispute exists. Indian mediators try to avoid such statements that elevate the dispute to an international level scale and reinforcing bilateralism. Technical descriptions and means abiding by the legal concerns help to give these concerns as neutral and objective, which conceals the facts laying beneath them in terms of politics and 
brings in technocrats and engineers as precise performers of law. This disguising of combat politics also allows the 'status quo to remain persistent under the support of collaboration and permits India to carry on its projects of construction. The wars of the next century will be over water (Wolf 1999), India and Pakistan's cooperation over the Indus waters seems to be an anomaly. The more valuable lesson of international water is as a resource whose characteristics tend to induce cooperation and incite violence only in the exception (Wolf, 1999).

To resolve and manage the issue of water inadequacy and other related challenges Pakistan should;

- Protect its ground-water aquifers through appropriate parameters that imply administrative and procedural measures such as controlling the design and development, water licensing, scientifically filling underwater resources in vulnerable areas through joined water administered projects.

- Adopt sensible underground water extraction and mining by implementing controls on excessive water pumping.

- Focus on water recycling by adopting advanced measures and using the best possible ways and using this water for commercial and agricultural purposes.

- Adopt measures to protect rivers and other water resources through the plantation, increasing the water storage capacity of dams and protecting hazardous water from reaching water sources.

- Introduce modern irrigation equipment and also give training and financial benefits to the farmers for using such systems.

- Control the mixing of saline water into Indus Deltaic Region and an appropriate flow of freshwater downstream of Kotri made an obligation.

- Use reasonable measures to secure and sustain the ecology of dry river reaches of the three eastern rivers diverted by India under the IWT 1960.

- Execute emergency plans helping lessen the water scarcity.

- Explore the propensity for joint watershed management of transboundary catchment areas with other nations.

- Use the international laws and forums to shield and guard Pakistan's rights on opposing boundary water inflows.

- Workout on having a water agreement with Afghanistan.

- Adopt and follow ecological conservation practices to promote integrated watershed management upstream.

\section{Conclusion}

For Pakistan, the Indus waters system is a lifeline, because most of the country's economy depends on the agriculture sector. Indus river and its tributaries are the primary sources of freshwater, and it supports $90 \%$ of the country's agricultural industry. Once Pakistan was considered relatively plentiful with water, but a mixture of mismanaged irrigation, waterintensive agriculture, and climate change has reduced the Indus water to fulfil Pakistan's future needs. A 2018 report from the IMF ranked Pakistan third among countries facing severe water shortages. When the rapidly melting glaciers in the Himalayas, which feed the Indus waters, eventually disappear as predicted, the dwindling rivers will be slashed even further. Such a scenario can be a catastrophe for Pakistan and India to feed their large population and to provide 
them jobs. To overcome this future issue good management of water resources and batter mechanism to solve the interstate dispute between India and Pakistan is the need of the time.

The management of South Asian water resources is a big initiative that can stop future conflict in the region. Because it encompasses so many differing interests, including hydropower, flood control, irrigation, fisheries, navigation, and environmental protection, it has spawned complex planning, development, and regulatory-statutory and institutional frameworks designed to address the problems in each of these countries.

Thus, the management of water resources in South Asia, as elsewhere, operates under the heavy burden of bureaucratic political pathologies. Apart from this, however, at least two others often overlooked managerial problems that adversely impact water resource policymaking exist: first, the paralysis of the policymaking process stemming in particular from the federal structure of governance in India and Pakistan and second, the systemic political nonaccountability that stems from the profound institutional weaknesses found in in the democratic or quasi-democratic setups of most South Asian states.

In the given circumstances India, Pakistan bitterness on the Kashmir issue is the biggest hindrance to resolve this water conflict. Indian move to abolish Articles 370 and 35A, which changed the special status of Jammu and Kashmir guaranteed by the Indian constitution, further increased the mistrust between the three nations. Any practical resolution among India, Pakistan, and Kashmir on the water issue, can only be achieved when an honourable future of divided Kashmiris will be guaranteed according to their determination.

\section{References}

Alam, U. Z. (2002). Questioning the water wars rationale: A case study of the Indus Waters Treaty. Geographical Journal, 168(4), 341-353. $\quad$ https://rgsibg.onlinelibrary.wiley.com/doi/abs/10.1111/j.0016-7398.2002.00060.x

Alam, U. Z. (1998). Water rationality: Mediating the Indus Waters Treaty. Doctoral Dissertation, Durham University. http://etheses.dur.ac.uk/1053/1/1053.pdf

Ali, S. H. (2008). Water politics in South Asia: Technocratic cooperation and lasting security in the Indus basin and beyond. Journal of International Affairs, 167-182. https://www.jstor.org/stable/24358117

Alvi, A. H. (1962). The Indus basin irrigation water dispute between India and Pakistan and the good offices of the World Bank. Doctoral Dissertation, University of Washington.

Barnett, M., \& Duvall, R. (2005). Power in international politics. International organization, 59(1), 39-75. https://www.cambridge.org/core/journals/internationalorganization/article/power-in-internationalpolitics/F5F3C74D30A12A5C4CC9B4EFEA152967

Biswas, A. K. (1992). Indus water treaty: The negotiating process. Water international, 17(4), 201-209. https://doi.org/10.1080/02508069208686140

Charles, R. (1987). The comparative method: Moving beyond qualitative and quantitative strategies. University of California

Dawn. (2002). Indus Basin Treaty to 'continue smoothly'. Dawn News.

Gorbachev, M. (2000). Out of water: The distant alarm comes closer. Civilization (OctoberNovember 2000), 82. 
Gulhati, N. D. (1973). Indus Waters Treaty: An exercise in international mediation. Allied Publishers.

Hurst. C K. (1956). Water in international affairs. Behind the Headlines, 16(3), 1-16.

Waltz, K. N., (2000). Structural Realism after the Cold War. International Security, 25(1). https://www.jstor.org/stable/2626772.

Keohane, R. O. (1986). Neorealism and its Critics. Columbia University. https://doi.org/10.1177\%2F002234338802500316

Klare, M. (2002). Resource wars: The new landscape of global conflict. Macmillan.

Michel, A. A. (1967). The Indus rivers: A study of the effects of partition. Yale University. https://doi.org/10.1177\%2F002088176801000417

Mustafa, D. (2001). Colonial law, contemporary water issues in Pakistan. Political Geography, 20(7), 817-837.

Outlook. (2005 March 20). Conflict over water between India-Pak "inevitable in future". https://www.outlookindia.com/newswire/story/conflict-over-water-between-indiapak-inevitable-in-future/287301

Presse, A. F. (2001, March 20). Water, the looming source of world conflict. Global Policy Forum https://archive.globalpolicy.org/security/natres/water/2001/0320cflt.htm

$(G P F)$.

Rausching, D. (1983). Indus water dispute. Encyclopedia of Public International Law, 2, $962-$ 964.https://www.elsevier.com/books/encyclopedia-of-public-internationallaw/bernhardt/978-0-444-86140-5

Rehman, A. U., Hakim, A., Khan, K., \& Khan, I. U. (2018). Role of CPEC in development of trade, transport and economy of Pakistan. Romanian Journal of Transport Infrastructure, 7(1), 77-92.

Salman M. A., \& Kishor, U. (2003). Conflict and cooperation on South Asia's international rivers: A legal perspective. World Bank Publications https://documents.worldbank.org/en/publication/documentsreports/documentdetail/249581468325224527/conflict-and-cooperation-on-southasias-international-rivers-a-legal-perspective

Siddiqi, T. A. (2004). An India-Pakistan détente: What it could mean for sustainable development in South Asia and beyond.

Tabassum, S. (2001). The role of CBMs in resolving non-military issues between India and Pakistan: A case study of the Indus Water Treaty. The Challenge of ConfidenceBuilding Measures in South Asia.

Tayyeb, A. (1966). Pakistan: A political geography. Oxford University. https://www.cambridge.org/core/journals/bulletin-of-the-school-of-oriental-andafrican-studies/article/tayyeb-pakistan-a-political-geography-xvi-250-pp-londonetc-oxford-university-press-1966-55s/8BFD05C0B1735C245BDE54D2D24EB87F

Wescoat Jr, J. L., Halvorson, S. J., \& Mustafa, D. (2000). Water management in the Indus basin of Pakistan: A half-century perspective. International Journal of Water Resources Development, 16(3), 391-406. https://doi.org/10.1080/713672507

Wirsing, R. G. (2007). Hydro-politics in South Asia: The domestic roots of interstate river Rivalry. Asian Affairs: An American Review, 34(1), 3-22. https://doi.org/10.3200/AAFS.34.1.3-22

Wolf, A. T. (1999). The transboundary freshwater dispute database project. Water International, 24(2), 160-163. https://www.tandfonline.com/doi/pdf/10.1080/02508069908692153 